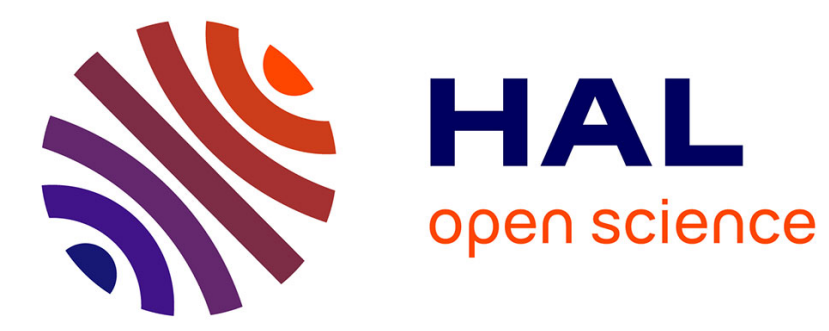

\title{
Coordination strategies and inclusory constructions in New Caledonian and other Oceanic languages
}

\author{
Isabelle Bril
}

\section{To cite this version:}

Isabelle Bril. Coordination strategies and inclusory constructions in New Caledonian and other Oceanic languages. Martin Haspelmath. Coordinating constructions, 58, Benjamins, pp.499-533, 2004, Typological studies in Language. halshs-00006064

\section{HAL Id: halshs-00006064 https://shs.hal.science/halshs-00006064}

Submitted on 23 Nov 2005

HAL is a multi-disciplinary open access archive for the deposit and dissemination of scientific research documents, whether they are published or not. The documents may come from teaching and research institutions in France or abroad, or from public or private research centers.
L'archive ouverte pluridisciplinaire HAL, est destinée au dépôt et à la diffusion de documents scientifiques de niveau recherche, publiés ou non, émanant des établissements d'enseignement et de recherche français ou étrangers, des laboratoires publics ou privés. 


\title{
Coordination strategies and inclusory constructions in New Caledonian and other Oceanic languages*
}

\author{
Isabelle Bril \\ LACITO-CNRS, Paris
}

1. Introduction

1.1. Oceanic languages

1.2. Introduction to Nêlêmwa

2. Noun phrase coordination in Nêlêmwa

2.1. The general dependency marker $m e$ 'and'

2.2. The animate, inclusory NP coordinator $m a$ 'and, with'

2.3. The additive coordinator $k a \sim x a$ 'and also, too'

3. Predicate and clausal coordination in Nêlêmwa

3.1. Me: a polyfunctional morpheme

3.2. Me and $x a$ as medial VP or clausal coordinators

3.3. Me, $n a$ and $x a$ in clause chaining

4. Typological comparisons with other Oceanic languages

4.1. Appositive inclusory constructions in some Oceanic languages

4.2. Inclusory, coordinating and comitative strategies: a comparative overview in some Oceanic languages

4.3. Inclusory constructions: paths of grammaticalization and replacement

5. Conclusion

\section{Introduction}

\subsection{Oceanic languages}

Oceanic languages, among which New Caledonian languages, are of some typological interest in that they tend to use various 'and' coordination markers for different categories of conjuncts (noun phrases, verb phrases or clauses), as well as for different subcategories of nouns (animate vs. inanimate), of verbs (stative vs. active) and of clauses (same-subject vs. different-subject clause coordination). For an overview, see Moyse-Faurie \& Lynch (this volume). Besides, each of these 'and' conjunctions have a predominant semantic feature (inclusory, comitative, additive) as well as specific syntactic properties.

The first part of this article is a detailed case-study of some of the coordinators in Nêlêmwa ${ }^{1}$, to be followed by some comparative data from other New Caledonian languages (Ajië, Bwatoo, Cèmuhî, Nyelâyu, Tîrî) and other Oceanic languages of Papua New Guinea (Manam, Tolai), the Solomon Islands (Toqabaqita), Vanuatu (Mwotlap) and Fiji (Boumaa Fijian). The relationship between these languages is shown in Figure 1, and references are given in the section "Language sources" at the end of the article.

\footnotetext{
* I am grateful to Martin Haspelmath for his insightful comments on an earlier version of this paper.

${ }^{1}$ All the Nêlêmwa data originate from my fieldwork.
} 


\subsection{Introduction to Nêlêmwa}

Nêlêmwa is one of the twenty-eight New Caledonian (or Kanak) languages, it is spoken in the Far North of the Mainland, by approximately a thousand speakers. The New Caledonian languages belong to the Remote Oceanic subgroup of the Eastern Oceanic subbranch of the Austronesian family (see the family map in Figure 1).

Here are some brief guidelines about the structure of the verb phrase in Nêlêmwa: Nêlêmwa has split constituent order and a split accusative-ergative casemarking system varying with argument category. Dependent personal pronouns, which only refer to human entities (inanimates are zero-marked) have an accusative system, while nominal arguments and free pronouns are case-marked as ergative or absolutive; the ergative case-markers are (e)a (for animate agents) and $r u$ (for inanimate agents), the absolutive case is zero. The neutral order is sVo with subject and object dependent pronouns referring to human entities (otherwise ØVØ), whereas nominal arguments come after the predicate, either as VS (where [S] is the absolutive nominal argument of an intransitive verb) or VOA (where O stands for the second argument/patient and A the agent of a transitive verb). The dependent subject pronoun cross-references the postverbal nominal prime argument (if human), irrespective of its absolutive or ergative case-marking and agrees in number with it, thus (s)VS, or (s)VOA; whereas the dependent object pronoun is always anaphoric to the nominal second argument.

The coordination markers listed in Table 1 are heads or operators which vary in their semantics and in their syntactic properties, displaying different functions and restrictions of usage. The contrastive marker $n a$ 'and, but' and the explicative marker $b u$ 'as, for, but' only conjoin clauses; whereas the general dependency marker $m e$ 'and', the additive marker $k a \sim x a^{2}$ 'also, too' and the disjunctive marker ai 'or' occur at all levels, phrasal (NPs or VPs) or clausal. Some of these morphemes are also restricted to more specific subcategories: the inclusorycomitative coordination marker $m a$ 'and, with' is normally restricted to human NP conjuncts and $x a$, but not me, may conjoin stative verbs. They also vary according to whether they conjoin entities symmetrically or asymmetrically and according to the type of number concord they trigger. Apart from their conjoining function, some of them also have adverbial function, especially $x a$ 'also, too' and $a i$ 'or', which is then equivalent to an English question tag with reverse polarity or to a suspensive marker 'or not'.

This study will concentrate on the general dependency marker me and the inclusory-comitative coordinator $m a$, leaving out the disjunctive marker $a i$ 'or' and the explicative-contrast coordinator $b u$.

NP coordination will be analyzed separately from VP, clausal and sentence coordination, as these exhibit different properties.

\footnotetext{
2 In modern Nêlêmwa, $x a$ is the predominant form, but in the texts recorded by Haudricourt (1963), $k a$ is as frequent as its allomorph $x a$.
} 
Table 1: Distribution of coordinators in Nêlêmwa

\begin{tabular}{|c|c|c|c|c|c|c|}
\hline \multirow[b]{2}{*}{ Function } & \multicolumn{6}{|c|}{ Type of coordination } \\
\hline & $\begin{array}{l}\text { inclusory } \\
\text { comitative }\end{array}$ & $\begin{array}{c}\text { general } \\
\text { dependency } \\
\text { marker }\end{array}$ & additive & disjunctive & $\begin{array}{c}\text { contrast, } \\
\text { adversative }\end{array}$ & $\begin{array}{l}\text { explicative, } \\
\text { contrast }\end{array}$ \\
\hline Form & $\begin{array}{c}m a \\
\text { 'and, with' }\end{array}$ & $\begin{array}{c}\text { me } \\
\text { 'and, and so } \\
\text { on, etc.' }\end{array}$ & $\begin{array}{c}x a \\
\text { 'also, too' }\end{array}$ & $\begin{array}{l}a i \\
\text { 'or' }\end{array}$ & $\begin{array}{c}\text { na } \\
\text { 'but, } \\
\text { whereas' }\end{array}$ & $\begin{array}{c}b u \\
\text { 'for, but' }\end{array}$ \\
\hline $\begin{array}{l}\text { Medial NP } \\
\text { coordinator }\end{array}$ & + & + & + & + & & \\
\hline $\begin{array}{l}\text { Medial VP } \\
\text { or predicate } \\
\text { coordinator }\end{array}$ & & + & + & + & & \\
\hline $\begin{array}{c}\text { Medial } \\
\text { clausal } \\
\text { coordinator }\end{array}$ & $\begin{array}{c}(+) \\
\text { (idiosyn- } \\
\text { cratic) }\end{array}$ & + & + & + & + & + \\
\hline \multirow{2}{*}{$\begin{array}{l}\text { Sentential } \\
\text { coordinator } \\
\text { (initial or } \\
\text { final posi- } \\
\text { tion) }\end{array}$} & & $\begin{array}{c}\text { sentence initial } \\
\text { (infrequent): } \\
\text { topic and } \\
\text { referential } \\
\text { continuity }\end{array}$ & & & $\begin{array}{l}\text { sentence initial } \\
\text { or medial: } \\
\text { topic and } \\
\text { referential } \\
\text { discontinuity }\end{array}$ & $\begin{array}{c}\text { sentence } \\
\text { initial } \\
\text { interrogative } \\
\text { 'so then?' }\end{array}$ \\
\hline & & & $\begin{array}{l}\text { sentence } \\
\text { final } \\
\text { 'also' }\end{array}$ & $\begin{array}{c}\text { sentence } \\
\text { final (rising } \\
\text { intonation): } \\
\text { confirmation } \\
\text { tag }\end{array}$ & & \\
\hline
\end{tabular}

\section{Noun phrase coordination in Nêlêmwa}

The various morphemes marking NP coordination, me (general dependency marker), $m a$ (inclusory), and $x a$ (additive), display specific semantic and syntactic properties, particularly in relation to number concord.

\subsection{The general dependency marker $m e$ 'and'}

The following is an example of $m e$ in its conjoining function.
I pajale ushi hlaaleny pwaxi-n me pabuu- $n$.
3SG tell BENEF these.DEICT child-POSS.3SG DEPEND grandchild-POSS.3SG
'He tells (the story) to his children and grandchildren.'

The medial coordinator $m e$ 'and' is a highly polyfunctional dependency marker; apart from coordination, it also marks some types of complement clauses, as well as adverbial purposive clauses (see §3.1.). That is why it is labeled "general dependency marker" and glossed as DEPEND. As a coordinator, me has few subcategorization constraints; it may conjoin NPs, VPs, clauses or it may be used as a sentence or clause chaining device to signal discourse and topic continuity, in contrast with $n a$ 'and, then, but' which marks topic discontinuity (see $\S 3.3$ ). Me is compatible with definite or indefinite, animate or inanimate NPs (as in mido me kuvic 'taros and yams'), but it normally excludes proper nouns which are conjoined 
by $m a .^{3}$

Negative clauses as well as the arguments of negative or negated predicates may be conjoined by me:

Na u kian shi-n me kua-n me bwaa-n.

CONTR PFC not be there arm-POSS.3SG DEPEND leg-POSS.3SG DEPEND head-POSS.3SG 'And then, he has no arms left, nor legs, nor head.'
Na thu da o kia oda-xua-ny
me oda-yi-ny?
$1 \mathrm{SG}$ do what? IRR there is no finger-foot-POSS.1SG DEPEND finger-hand-POSS.1SG

'What shall I do if I have no toes nor any fingers (left)?'

$\mathrm{Me}$ does not require obligatory number concord with the conjoined arguments. Loose, afterthought-like conjuncts do not trigger number concord (which is marked on the subject index), as in (4):

$$
\begin{aligned}
& \text { Mwelî xe } \boldsymbol{i} \text { taabwa Teâ Nyanyaloon } \\
& \text { there TOP 3SG Stay T. N. } \\
& \text { 'There lived Teâ Nyanyaloon and his wives ... }
\end{aligned}
$$

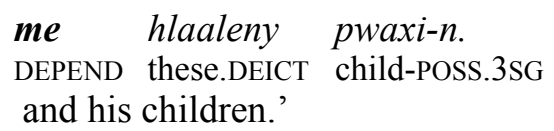

Johannessen (1998) calls such constructions "unbalanced coordination", unbalancedness being defined as "due to some grammatical property lacking or being different in one conjunct compared to the other, i.e., one conjunct may have different case-marking from the other or lack number-marking" (1998:8). This is interpreted as a sign that the unbalanced conjunct is a complement headed by the conjunction (1998:113-16). Synchronically, concord or lack of concord in Nêlêmwa varies with semantic and discourse factors; a diachronic argument is also suggested for this state of affairs (see $\S 4.3 .4$ ).

Me may very marginally be used in place of the normally expected non-co-agentive 'with' morpheme ve (+inanimate), vi (+animate) 'with', which refers to a patient that is brought or carried (see $\$ 2.2 .4$.):

$$
\begin{aligned}
& \text { Hli u oda-me hli me hlaaleny } \text { shâlaga } i \quad h l i . \\
& \text { 3DU PFC go up-DIR 3DU.FR DEPEND these.DEICT } \\
& \text { 'They come back with their crabs.' }
\end{aligned}
$$

When used as a postpositive coordinator, me is an open list marker meaning 'and so on, etc.'. A pause after each me signals that it is prosodically part of the NP to its left, over which it has scope, and the list ends with a final occurrence of me. Listing with $m e$ is restricted to inanimate entities and has no counterpart for animate entities, which are coordinated medially with $m a$ (see §2.2.1.).

$$
\begin{aligned}
& \text { I xau mwemwelî roven hleena yada-va } \\
& \text { 3SG ASS know.TR all these.DEICT } \\
& \text { 'He knowsect-POSS.1PL.EXCL }
\end{aligned}
$$

$$
\begin{aligned}
& \text { Hla khuxi mugic me, mido me, kuvic me... } \\
& \text { 3PL eat.TR banana DEPEND taro DEPEND yam , DEPEND } \\
& \text { 'They eat bananas and taros and yams, and so on.' }
\end{aligned}
$$

\footnotetext{
3 Only one exception was found in the whole corpus:

Hâ xam no axaleny Wilion me Bula.

1PL.INCL ASS look this.DEICT, Wilion DEPEND Bula

'We look up to Wilion and Bula.' (to know what to do).
} 
The list may be reduced to one occurrence, with a suspensive me:

$$
\begin{gathered}
\text {..f fexa hlaaleny delek me... } \\
\text { matter these.DEICT land DEPEND } \\
\text { '...about this land matter and so on.' }
\end{gathered}
$$

Listing with the postpositive me corresponds to asyndetic coordination in other languages ('they eat bananas, taros, yams, and so on'), but asyndetic NP coordination is not a possible option in Nêlêmwa.

\subsection{The animate, inclusory NP coordinator $m a$ 'and, with'}

In contrast with me, $m a$ only conjoins animate NPs (represented by proper or common nouns) and triggers obligatory number concord with the conjuncts. It may conjoin NPs symmetrically or asymmetrically, as shown below.

\subsubsection{Symmetric NP coordination}

In symmetric constructions, ma conjoins contiguous NPs which must belong to the same category, have the same semantic role and the same syntactic function, such as agents in $(9,10)$ and locative adjuncts in $(11)$.
Hli pe-kâlaxi
kââma-n
ma
axomoo- $n$
3DU REC-be.ashamed father-POSS.3SG COORD mother-POSS.3SG
'His father and mother are ashamed of each other.'

In (10), the NPs conjoined by $m a$ are cross-referenced by the dual subject pronoun $h l i$, whereas the NP conjoined by me is a loose conjunct which is not cross-referenced by the subject pronoun.

$$
\begin{aligned}
& \text { Hli } u \text { muuvi mwa Kaavo Dela ma Teâ Pwayili Uvea me } \\
& \text { 3DU PFC stay ASS Kaavo Dela COORD Teâ Pwayili Ouvéa DEPEND }
\end{aligned}
$$

aax-iik pwaxi-hli.

CLF-one child-POSS.3SG

'Kaavo Dela and Teâ Pwayili of Ouvea then stayed there, as well as their child.' (or: '....with their child.')

In (11), the NPs kâama- $n$ and axomoo- $n$ are two locative adjuncts, headed by the nominal preposition shi and cross-referenced by the dual deictic pronoun hlileny:

(11) I uya shi hlileny kââma-n ma axomoo-n ...

3SG arrive side these2.DEICT father-POSS.3SG COORD mother-POSS.3SG

'He arrives at his father's and mother's.' (lit. He arrives at these $\mathrm{dual}_{\text {father }}$ and mother)

In symmetric constructions, ma has commutative properties, the order of the conjuncts, (ak ma thaamwa 'men and women' or thaamwa ma ak) varies with discourse and pragmatic factors.

$M a$ may have listing function, but in contrast with me which is a postpositive marker with the listing function, $m a$ remains a medial marker that symmetrically conjoins a series of NPs.

$$
\begin{aligned}
& \text { Hla oda-me hlaaleny aavak thaxamo } i \text { ye: } \\
& \text { 3PL go.up-here these.DEICT four wife CONN 3SG } \\
& \text { 'His four wives come up here: }
\end{aligned}
$$

horaamwaleny Naan ebai ma Naabuc ma Deedan ma Naalôop. this.woman.DEICT fly ANAPH COORD mosquito COORD horsefly COORD small.fly Fly, and Mosquito, and Horsefly, and Small Fly.'

Asyndetic coordination is not normally used; the only case when proper nouns may be asyndetically conjoined is when they are part of appositive NPs in complement function (13), but not as independent NPs: 
Me $i$ thoogili hlaaleny thaxamo $i$ ye, horaamwaleny Naabuc DEPEND 3SG call.TR these.DEICT wife REL 3SG this woman.DEICT mosquito 'And he calls his wives, Mosquito,

thaamwa Nêlêmwa, ma Naan thaamwa Nixumwak, Ø Naalôop woman Nêlêmwa COORD fly woman Kumak small fly the Nêlêmwa woman, and Fly, the Kumak woman, Small Fly,

thaamwa Puuma, Ø Naadoolan thaamwa Mweleebeng. woman Puuma green.Fly woman Mweleebeng the Puuma woman, Green Fly, the Mweleebeng woman.'

$M a$ is also used as a post-nominal marker meaning 'and company, and fellows' probably resulting from an ellipted noun: Teâ-ma 'the chief' (lit. the chief and fellows), Nenema-ma 'the Nenema' (as a clan), aayo-ma 'the great chief', hulak-ma 'the respected ancestors'. It has become a formula expressing respect due to rank and age. This is common in New Caledonian and other Oceanic languages. In Manam (Western Oceanic), the form guma 'and fellows' has exactly the same meaning: Oniau guma 'Onkau and his fellows' (Lichtenberk 1983:436).

\subsubsection{Asymmetric inclusory coordination}

Ma may have both asymmetric (cf. 14) and symmetric (cf. 15) inclusory functions. The term "asymmetric inclusory" (or "split inclusory" in Lichtenberk's terminology) refers to cases when the conjunct NP headed by ma is not phrasal but included as a subset of the arguments referenced by the subject pronoun, whereas the symmetric case conjoins two NPs, as in (15). Occurrence in asymmetric inclusory constructions as in (14) are a distinctive property of $m a$, which is not evidenced by me. Thus, the free pronoun yaman 'we two' includes the unmentioned speaker and the referent expressed by the deictic pronoun axaleny.

$$
\begin{aligned}
& \text { Co xam kua axi-na, yaman ma axaleny o ma oda } \\
& \text { 2SG ASS often see-1SG 1DU.EXCL.FR COORD this man IRR 1DU.EXCL go up } \\
& \text { 'Have you often seen me, me and this man (lit. we dual including this man), go up } \\
& \text { yaage fexa yameewu } i \text { yo? } \\
& \text { look for affair clan CONN 2SG } \\
& \text { and meddle into the affairs of your clan?' }
\end{aligned}
$$

Thus, in asymmetric inclusory constructions, the non-singular pronoun $(\mathrm{x})$ includes the reference to the $m a$-headed NP (y) [y $\varepsilon \mathrm{x}$ ], but does not add up with it $\left[{ }^{*} \mathrm{x}+\mathrm{y}\right]$.

Example (15) shows both constructions: the symmetric (phrasal) construction in the first part of the sentence, and the asymmetric construction in the second part.

(15) Na hli u ulep dagiiny ma axaleny TeâPaak, hla ma Kaavo. CONTR 3DU PFC go out messenger COORD this.DEICT Teâ Paak 3PL.FR COORD Kaavo 'But the messenger and Teâ Paak leave, they (two) and Kaavo.' (lit. 'they plural including Kaavo')

In the second part of (15), Kaavo is included in the plural free pronoun: hla ma Kaavo 'they(plural) including Kaavo'; the additive construction is ungrammatical (*hli ma Kaavo 'they(dual) and Kaavo'), which suggests the syntactic constraint that only nouns can be symmetrically conjoined, but not a pronoun and a noun.

Similarly, in (16), ma does not conjoin fwamwa and khola-ny, but it asymmetrically includes khola-ny in the set of the possessors of fwamwa, marked by the first person dual possessive pronoun -man, which includes an implicit speaker. 
Fwamwa-man ma hobai khola-ny.

country-POSS.1DU.EXCL COORD that.ANAPH uncle-POSS.1SG

'(It's) my village and my uncle's.' (lit. our village and/with my uncle)

In (17), the first $m a$ is a case of asymmetric inclusory construction, whereas the second occurrence symmetrically conjoins the two NPs kâama-m and axomoo-m, although this might also be analysed as an iterated inclusory construction with $m a$. All the conjuncts are cross-referenced by the second person plural possessive pronoun -wa which includes an implicit addressee.

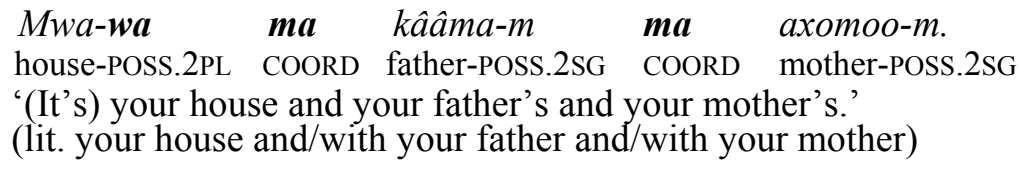

In (18)-(20) the $m a$-headed NP is included in the set of the dual possessive determiners of the nominal predicate fââlâ 'way' or kau 'year'.

(18) Pe-fââlâ-hli me ma ti?

REC-way-POSS.3DU DIR COORD who?

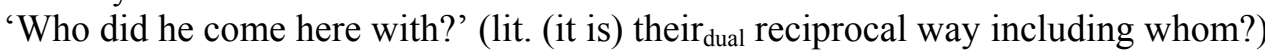

Pe-fââlâ-man ma ye.

REC-way-POSS.1DU COORD 3SG.FR

'I travelled with him.' (lit. (It's) our reciprocal way including him)

(Or:) 'He and I travelled together.'

Pe-kau-hli ma Yul.

REC-year-POSS.3DU COORD Jules

'He is as old as Jules.' (lit. (it is) their dual reciprocal age including Jules)

Given that dependent pronouns are preverbal but nominal arguments are postverbal in Nêlêmwa [sVS], there are cases when the coordinator $m a$ appears outside contiguous NPs, as in (21)-(23). In (21), the dual NP hlileny thaxamo 'these two wives' is included in the set of the agents of the process marked by the plural subject pronoun hla. The translation of $m a$ as 'and' or 'with' is misleading and $m a$ would more accurately be translated by 'including'.

Hla $u$ oda mwa ma hlileny thaxamo.

3PL PFC go up ACT COORD these2.DEICT wife

'He went south with his two wives.' (lit. they went including his two wives)

(Or:) 'He and his two wives went south.'

Io ma tu haga ma Polie.

FUT 1DU.EXCL go down fish COORD Polie

'I'll go fishing with Polie.' (lit. we dual will go fishing including Polie)

(Or:) 'Polie and I will go fishing.'

Similarly, in (23), the interrogative pronoun $t i$ is a subset of the dual subject index hli:

(23) Hli u muuvi ma ti/ri?

3DU PFC stay COORD who?

'Who did (s)he live with?' (lit. they dual $_{\text {live together including whom?) }}$

Similar constructions exist in other northern New Caledonian languages, in Nyelâyu (Far North) and Bwatoo (North):

(24) Nyelâyu (Ozanne-Rivierre 1998: 118)

Hor ma ri?

2DU COORD who?

'Who are you with?' (Or:) 'You and whom?'(lit. you dual including whom?) 
Bwatoo (Ehrhart and Rivierre, forthcoming)

(25) Bu vadi ma daahma.

1DU.EXCL work COORD chief

'I (lit. we $\mathrm{dual})$ am working with the chief.'

(26) Be thau hane ma hio ne-ong.

1PL.EXCL together leave COORD elder brother REL-POSS.1SG

'We leave together with my elder brother.'

(27) Lu ve-vulo ma tramo-thiita.

3DU REC-speak COORD sister

'He (lit. they dual) talks with his sister.'

Compare Nêlêmwa (28) and Bwatoo (29):

(28) Hli pe-rui ma ti?

3DU REC-meet COORD who?

'Who did she meet (with)?' (lit. they dual met including whom?)

Bwatoo (Ehrhart and Rivierre, forthcoming)
$\mathrm{Bu}$ ve-cipe ma a.
1DU.EXCL REC-meet COORD 3SG
'I met him.' (lit. we $\mathrm{dual}_{\text {dul }}$ met including him)

\subsubsection{Syntactic and hierarchy constraints in asymmetric inclusory constructions}

The first syntactic constraint imposed by $m a$ in Nêlêmwa is sameness of category, of syntactic function and semantic role. This accounts for the fact that only nouns can be symmetrically conjoined by $m a(\mathrm{~N} m a \mathrm{~N})$ in Nêlêmwa. All other types of conjuncts trigger asymmetric constructions, in contrast with English, which has no constraint of sameness of category as evidenced by he and his two wives went south vs. he and I will leave soon.

The second constraint in asymmetric constructions is the person hierarchy $(1>2>3)$. The choice of the inclusory pronoun which cross-references all the implicit or explicit conjuncts is controlled by a person hierarchy and referentiality. Consider (30) and (31), where the pronouns $m o$ and ha cross-reference the $m a$ headed NP and the implicit addressee (30) or speaker (31). First and second person being the highest on the referential hierarchy, they will include the participants lower in the hierarchy, i.e. a third person pronoun or a noun, as in (30).

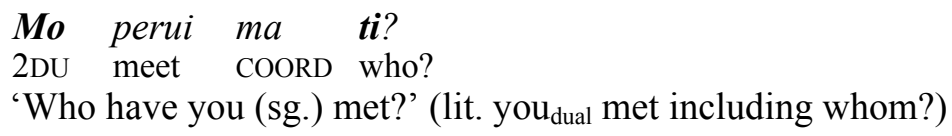

In (31a), a police officer orders two young men to meet him the next day (first person includes second person) and they answer (31b):

(31)a. Io hâ xam perui ma yamon caae.

FUT 1PL.INCL ASS meet COORD 2DU.FR tomorrow

'You'll meet me (here) tomorrow.' (lit. we will meet including you dual)

b. Elo, io hâ perui ma co.

yes FUT 1PL.INCL meet COORD 2SG.FR

'All right, we'll meet you (here).' (lit. we will meet including you)

Any divergence from this constraint is due to discourse and pragmatic reasons. Thus, in (32), the $1^{\text {st }}$ dual inclusive pronoun $h \hat{\imath}$ includes the speaker and the addressee, the expected conjunct would be $m a$ co 'with you', rather than $m a n a$ 'with me'. The inversion in person hierarchy is contextual: being blind, the speaker is dependent on the addressee who is also the initiator. 
Bu o hî tu haga ma na xe yo haga co, ...

EXPL IRR 1DU.INCL go down fish COORD 1SG.FR TOP 2SG fish 2SG.FR

'But, when we go fishing (you) and me, you [can] fish, you...

bu fo idaama-m.

EXPL there is eye-POSS.2SG

since you have your eyes.' (but not the speaker who lost hers)

In (33), note the mismatch between the inclusory dual pronoun hli and the singular possessive pronoun $(-n)$ which refers to the implicit referent.

\section{Hli ma aaxiik kaari-n. \\ 3DU COORD CLF-one sister-POSS.3SG}

'She and her elder sister.' (lit. they dual including her elder sister)

Thus, in the present state of the system, $m a$ functions both as a medial, symmetric coordinator in phrasal NP constructions (NP $m a \mathrm{NP}$ ) and as an inclusory coordinator in asymmetric constructions, a property that distinguishes it from the coordinator $m e$.

The latter constructions include an implicit referent, which is retrievable thanks to the person hierarchy, context or speech situation. Without this inclusory property, the implicit referent would have to be accounted for in terms of an ellipted NP, but syntactic reasons as well as typological and comparative data will be cited in $\S 2.2 .6$. against the notion of ellipsis.

The other question is whether $m a$ in the symmetric and asymmetric constructions should be considered as two homophonous morphemes, one being a coordinator and the other a comitative marker. This question will be addressed now.

\subsubsection{Ma: a comparison with comitative markers}

Though ma may sometimes translate as 'with', it is not a comitative preposition as will become clear below. There are two sorts of comitative markers in Nêlêmwa and many other New Caledonian languages, the co-agentive 'with' and the non-coagentive 'with' (glossed ASSOC "associative"). In Nêlêmwa, the co-agentive comitative role may also be marked by a different construction, with a nominal preposition mudi- or buli-4 'with, in company of', which heads a possessive adjunct that ranks lower and thus does not trigger number concord:

Co tuume mudi-ny.

2SG go.down company-POSs.1SG

'Go down with me.'

As for the non-co-agentive 'with', it is marked by the preposition $v e$ (+inanimate), vi (+animate), which grammaticalized through serialisation from the verb fhe 'carry, take' into an applicative or preposition-like affix heading an oblique argument which is excluded from number agreement.

(35) I gaa yиup ve hî para nu na mwada.

3SG PROG crawl ASSOC this crumb coconut LOC up.there

'It (an ant) crawls across with this crumb of coconut inside (the house).'

I fuk vi Kaavo a hooli maalîc.

3SG fly ASSOC Kaavo AGT that.ANAPH bird

'The bird flies with Kaavo (on its back).'

Various northern New Caledonian langages evidence similar distinctions between an inclusory coordinator and a non-co-agentive preposition. Cèmuhî (Rivierre 1980:194-95) distinguishes the inclusory coordinator me that triggers

\footnotetext{
${ }^{4}$ bole- in the neighbouring language Nyelâyu.
} 
number agreement and the non-co-agentive preposition imi 'with, carrying', derived from the verb imwi 'seize, hold' (Ozanne-Rivierre, to appear), which excludes number agreement. Bwatoo also distinguishes the inclusory coordinator $m a$ and the non-co-agentive preposition $f e$ derived from the verb $f e$ 'take, carry'.

(37) Bwatoo (Ehrhart and Rivierre, forthcoming)

A tobwaa-fe a mwa-thito.

3SG run-ASSOC ART bag

'(S)he runs carrying the bag.'

In Nêlêmwa, both the inclusory feature of $m a$ and the requirement that the NPs have the same syntactic function and semantic role, help understand why it (and never the non-co-agentive preposition $v e, v i$ ) appears in reciprocal and comparative constructions.

(38) Nêlêmwa:

Hli pe-vhaa ma axomoo- $n$.

3DU REC-speak COORD mother-POSS.3SG

'He and his mother speak to each other.' (lit. they dual $_{\text {speak including his mother) }}$

\subsubsection{Ma : a homophonous comitative preposition in Nêlêmwa?}

First, the fact that $m a$ can translate as a co-agentive, comitative 'with' in asymmetric constructions, as in I went fishing with him, results from the fact that, in such a case, it conjoins agents. But this is only one among the several possible semantic roles or syntactic functions that ma may conjoin. Besides, some syntactic tests developed below prove that it is not an adjunct-heading comitative preposition.

In English, extraction (e.g. topicalization or wh-movement) is a useful test to distinguish a preposition from a coordinator in (who did you go with? but * who did you go and?; with whom did you go? but * and who did you go?), but such tests are not discriminating in Nêlêmwa, since prepositions can never be topicalized with the NP, but must remain in situ with a resumptive anaphoric pronoun referring back to the topicalized NP. Compare the following constructions with the associative preposition $v i$ on the one hand, and with $m a$ on the other; topicalization and cleft constructions do not evidence any syntactic difference, since a resumptive independent pronoun appears in both cases:

(39)a. Io $i$ mu vi hoona âlô eli.

FUT 3SG stay ASSOC this.DEICT child this.ANAPH

'She's going to adopt that child.'

b. Ye hoona âlô eli io $i$ mu vi ye.

3FR this.DEICT child this.ANAPH FUT 3SG stay ASSOC 3SG

'Here's the child she's going to adopt.' (presentative construction)

(40)a. Ma pwe wuung ma thaamwa bai.

1DU.EXCL fish together COORD woman that.ANAPH

'I went fishing with that woman.'

b. Thaamwa bai xe ma pwe wuung ma ye. woman that.ANAPH TOP 1DU.EXCL fish together COORD 3SG 'That woman, I went fishing with her.'

c. Thaamwa bai hooli ma pwe wuung ma ye. woman that.ANAPH that.ANAPH 1DU.EXCL fish together COORD 3SG 'It is that woman that I went fishing with.'

The main difference lies in the conjoining properties of $m a$ vs. $v i \sim v e$. Only $m a$ may conjoin NPs and, in asymmetric constructions, the inclusory pronoun and the 
$m a$-headed NP may be topicalized as a complex NP (40d), which supports the notion of coordination against that of a preposition.

d. Yaman ma thaamwa bai xe ma pwe wuung. 1DU.EXCL.FR COORD woman that.ANAPH TOP 1DU.EXCL fish together 'Me and that woman, we went fishing together.'

In contrast, $v e \sim v i$ has no conjoining properties. The two arguments in $i$ fuk vi Kaavo 'he flew with Kaavo' (see 36) cannot be topicalized as a complex NP (*ye vi Kaavo xe i fuk), since they belong to different constituents and do not have the same syntactic functions. Similarly, in the asymmetric construction with $m a$ (41a, b, c), either the inclusory pronoun (41b) or the whole complex NP may be topicalized (41c):

(41)a. Mo tu yhalap ma ri/ti?

2DU go.down gather COORD who?

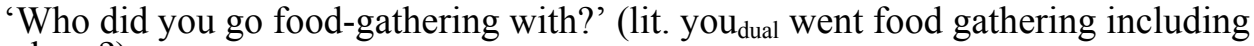
whom?)

b. Yamon xe mo tu yhalap ma ri/ti?

2DU.FR TOP 2DU go.downgather COORD who?

'You, you went food-gathering with whom?'

c. Yamon ma ri/ti me mo tu yhalap?

2DU.FR COORD who? DEPEND 2DU go.down gather

'With whom did you go food-gathering?' (lit. you dual $_{1}$ including whom and you dual went food gathering)

\subsubsection{Asymmetric constructions with ma: a case of ellipsis?}

In some languages, asymmetric constructions may result from ellipsis, but this is language-specific and cannot be generalized. In Boumaa Fijian, the asymmetric construction in (42a) is the usual form, with an ellipted pronoun which, if present as in (42b), is emphatic:

(42) Boumaa Fijian (Dixon 1988:157-61)

$\begin{array}{lllll}\text { a. 'Eirau } & \text { aa } & \text { sota vata 'ei } & \text { Jone mai Viidawa. } \\ \text { 1DU.EXCL } & \text { PAST meet together with John at } & \text { Viidawa }\end{array}$

'John and I met at Viidawa.' (1988:157)

b. 'Eirau aa sota vata o yau 'ei Jone mai Viidawa. 1DU.EXCL PAST meet together ART 1SG with John at Viidawa

'John and I met at Viidawa.' (1988:157)

But the case for ellipsis is not supported in Nêlêmwa, as there are syntactic restrictions on asymmetric and symmetric constructions. Only nominals can appear in symmetric phrasal constructions (43a); in constrast, in asymmetric inclusory construction, pronouns are always implicitly cross-referenced in the inclusory pronouns (43b), and the person hierarchy helps retrieve the implicit referent:

(43)a. Hli pe-boima axomoo-n ma pwaxi-n thaamwa.

3DU REC-kiss mother-POSS.3SG INCL child-POSS.3SG woman

'The mother and her girl kiss each other.'

b. Hli pe-boima Ø ma pwaxi-n thaamwa.

'She and her girl kiss each other.' (lit. they dual $_{\text {kiss including her girl) }}$

Such a syntactic restriction supports the notion that no NP ellipsis needs to be posited to account for asymmetric inclusory constructions in Nêlêmwa. Apart from this syntactic, language-specific reason, some typological features in Oceanic languages downplay the explanatory value of ellipsis, in particular the existence of appositive, conjunction-free inclusory constructions. This will be developed in $\S 4$. 


\subsection{The additive coordinator $k a \sim x a$ 'and also, too'}

The additive conjunction $x a$ (the form $k a$ is less commonly used in modern speech) may conjoin NPs, VPs or predicates and clauses. This section will just be concerned with NP coordination, in which case $x a$ is a medial NP coordinator which triggers number concord with the conjuncts (cf. 44) and is also used in sums and numeration (cf. 46).

(44) Hla u oda mwa hlileny thaamwa xa ye.

3PL PFC go.up ACT these2.DEICT woman also 3SG.FR

'These (two) women and he then go up.'

Kia kua-n bu u fagau-t hada $x a$ shi-t.

there.is.no leg-POSS.3SG EXPL PFC body only also arm

'She has no legs, but only a body and arms.'

(46) tujic $\boldsymbol{x a}$ bwaa-t pwa-giik

ten also top CLF-one

'Eleven.'

In adverbial function, $x a$ is no longer a medial marker, but has scope over the preceding item (whether NP, VP or predicate) and is followed by a slight pause.
Awa-hla me hla vhaa xa.
will-POSS.3PL DEPEND 3PL talk too
'They wanted to talk too.'

$$
\begin{aligned}
& \text { Hli xa fhe hî wany. } \\
& \text { 3DU also take this boat } \\
& \text { 'They too take this boat.' }
\end{aligned}
$$

The properties of the three NP coordinators are summarized in Table 2.

Table 2: Summary of the coordinators and their properties

\begin{tabular}{|l|c|c|}
\cline { 2 - 3 } \multicolumn{1}{c|}{} & $\begin{array}{c}+/ \text {-sameness of semantic role and } \\
\text { syntactic function between NPs }\end{array}$ & $\begin{array}{l}\text { number } \\
\text { concord }\end{array}$ \\
\hline$m e$ & $+/-$ sameness & $+/-$ \\
\hline$m a$ & + sameness (inclusory) & + \\
\hline$x a$ & + sameness (additive) & + \\
\hline
\end{tabular}

\section{Predicate and clausal coordination in Nêlêmwa}

All the coordinators listed in Table 1 mark clausal coordination: two of them, the contrast marker $n a$ 'and, but, whereas', which signals topic and referential discontinuity, and the explicative $b u$ 'for, but' are restricted to clausal coordination. As for VP coordination, coordinators are fewer and restricted to $m e \sim m a$ 'and', $x a$ 'and also, too' and $a i$ 'or'.

The analysis here will concentrate on three of them, me ma, na and $x a$. They differ with respect to three parameters of variation: (i) same vs. different subjects constraints, (ii) sequential vs. simultaneous semantics, (iii) topic continuity vs. discontinuity.

As a VP and clause coordinator, me refers to sequential actions and is compatible with same or different subjects; $x a$ refers to simultaneous or almost simultaneous actions and requires same subjects. As clausal coordinators, both me and $x a$ evidence topic continuity, in contrast with $n a$, which signals topic discontinuity. 


\subsection{Me: a polyfunctional morpheme}

Apart from indicating NP, predicate/VP and clausal coordination, the general dependency marker $m e$ is also a complementizer, as well as a subordinator in purposive clauses (see §3.1.3). In contrast with the distinctive distribution of inclusory $m a$ and non-inclusory $m e$ and the tight constraints on their use in NP coordination, the distribution of $m a$ and $m e$ in clausal coordination, complementation or subordination is not distinctive and allows some free variation.

\subsubsection{Me in VP coordination}

Only me appears in VP coordination ( $m a$ is excluded):

$$
\begin{aligned}
& \text { I xam wâlem, wâlem me wâlem me gi me ôoxi. } \\
& \text { 3SG ASS walk walk DEPEND walk DEPEND cry DEPEND go.away } \\
& \text { 'She walks, walks and walks and cries and goes away.' }
\end{aligned}
$$

But in Nixumwak (Nêlêmwa's neighbor), me and $m a$ seem to alternate freely for VP and clausal conjuncts. And further to the south-west, in Bwatoo ${ }^{5} m a$ coordinates NPs ${ }^{6}$, VPs and clauses.

\subsubsection{Me ma in clausal coordination}

In constrast with VP coordination where $m a$ is excluded, there is some free variation between $m e$ and $m a$ in clausal coordination in Nêlêmwa, mostly due to the idiosyncratic usage of some speakers who also happen to originate from or to have been in contact with a neighbouring language where $m a$ and $m e$ seem to alternate freely, as in Nixumwak (to the south) or where $m a$ is the predominant form, as in Nyelâyu (to the east). In Nyelâyu, $m a$ 'and, with, so that' 7 conflates all the functions and meanings expressed by the two markers in Nêlêmwa. Compare Nêlêmwa me da? 'what for?' and Nyelâyu ma da? 'what for?' (lit. and/so that what?). And since there is no structural necessity to maintain any distinction between them in clausal coordination, $m a$ can be tolerated in the Nêlêmwa system. Such confusion also illustrates the tendency to reduce the number of coordinators, especially when non-distinctive, and to conflate their meanings. Thus, though $m e$ is the "expected" form, ma appears quite often in such environment; in (50), both forms appear in the same sentence:

$$
\begin{aligned}
& \text { Tuu-me axaleny Pwayili me } \quad \text { me tuu-me kêlâ fâalô ... } \\
& \text { go.down-DIR this.DEICT Pwayili DEPEND 3SG go.down-DIR join path } \\
& \text {...nai ye a Kaavo ma hli } u \text { tu. } \\
& \text { LOC 3SG AGT Kaavo DEPEND 3DU PFC go.down } \\
& \text { 'Pwayili goes down and Kaavo goes down and joins him and they both go down.' }
\end{aligned}
$$

\subsubsection{Me as a complementizer and subordinator}

The following examples illustrate two other functions of me, that of complementizer $^{8}$ (51a) and subordinator in purposive clauses (51b).

\footnotetext{
5 Other conjunctions of Bwatoo: $k a$ (sequential, consequence, constrast marker, also associated with stative verbs), $b w a$ (addition), thaan 'but' (contrastive), hai 'or' (disjunctive).

6 vwen ma kahuen 'turtle and sea-cow' (name of a type of sugar-cane).

7 Other conjunctions: cha 'too, also' (cf. Nêlêmwa $x a$ ), ta 'and, then', kam 'but' (contrastive).

8 Associated with some types of verbs: jussive verbs (khabwe me 'tell to'), conative verbs (shaxami me 'try to', yaage me 'attempt to'); telaxi me 'ask to'; nanami me 'plan to'; pe-whan me 'promise to'; Aktionsart verbs (thaaxa(puxet) me 'begin to', diya me 'get ready to'), taau me 'wait to'.
} 
(51a) I khabwe shi Pwayili me i $\hat{a}$

3sg say side Pwayili DEPEND 3Sg leave

'He tells Pwayili to leave.'

(51b)

Io ma $\quad$ pajale
FUT
1DU.EXCL tell

'We'll tell our children and grand-children tomorrow so that they know.'

The function and meaning of Nêlêmwa me is context-dependent and sometimes ambiguous (as in 52, 53); but so is pseudo-coordination in English try and/to do it.

Na $\hat{a}$ shi Pwâ-Kebö me ma haga wuung ma ye.

1SG leave side Pwâ-Kebö DEPEND 1DU.EXCL fish together COORD 3SG

'I'm going to Pwâ-Kebö's and we'll go fishing together.' (Or:) '[...] to go fishing together.'

Pwâ ôoxi me yo shaavic mwa.

a.little go.forward DEPEND 2SG warm.up ACT

'Come a little closer and get warm.'(Or:) 'Come a little closer to get warm.'

The ambiguity is lifted with negation, as in (54), where the scope of the negation kio over both clauses furthers the interpretation of $m e$ as the complementizer of the nominal predicate kâyaa, not as a coordinator, and similarly in (55) with the negative predicate kia:

(54) [Kio kâyaa nai yava [me va kûxû o wi]].

NEG habit LOC 1PL.EXCL.FR DEPEND 1PL.EXCL drink CONN water

'We are not used to drinking water.' (* we are not used to it and we drink water)

[Kia yeewa-n [me $i$ horêan]].

there.is.not time-POSS.3SG DEPEND 3SG breathe

'He has no time to rest.' (* he has no time and he rests)

Me (or $m a$ ) also appear in correlative constructions in association with the quantifier/intensifier $h m a$ 'much, a lot' to express consequence:

Hma tabö kot me $\sim \boldsymbol{m a}$ kââlek o na a Pum.

a.lot fall rain DEPEND impossible IRR 1SG go Poum

'It rained so much that I cannot go to Poum.'

Polyfunctionality may result from a general tendency for fusion and conflation of several markers. In New Caledonia, Cèmuhî (Rivierre 1980:196) suggests such an evolution, the coordinator and subordinator are distinguished by their tone: $m e$ without a tone of its own is the NP coordinator triggering number concord with the conjuncts, as well as the inclusory coordination marker, while me with middle tone has complementizing and subordinating functions, expressing adverbial purposive clauses '(so) that'. Were it not for their tonal difference, they would merge as they have merged in Iaai, Nêlêmwa and Nyêlayu. In Nyelâyu, me is both a coordinator and a complementizer (Ozanne-Rivierre 1998:123); further south, in Yuanga 9 (Haudricourt, n.d.), ma coordinates NPs referring to humans, and is also an explicative conjunction meaning 'for, because'; me in Iaai marks the comitative, coordination (NP or clausal coordination) and complementation (Ozanne-Rivierre 1976:138-41). More marginally, $m w \hat{a}$ in Tîrî is also a clausal coordinator and a complementizer (Osumi 1995:260). Such polysemous and polyfunctional dependency markers are not uncommon in Oceanic languages ${ }^{10}$. Lichtenberk

\footnotetext{
9 In Yuanga: ma (+NP), meni (+non-human), ai 'or', munaale 'then', xo 'too', axe 'but'.

10 For examples of polyfunctional morphemes in other languages, in particular the subordinating and coordinating functions of $k e$ in Greek, see Johannessen (1998:241).
} 
discusses the even broader range of functions of the conjunction be in Manam (1983:515-26), which, besides NP and clause coordination, also marks a variety of other functions such as temporal adverbial clauses (simultaneous or sequential) and clauses of purpose, cause, result, condition and contrast.

\section{2. $M e$ and $x a$ as medial VP or clausal coordinators}

Apart from their semantics, $m e(\sim m a)$ 'and' on the one hand, and the additive conjunction $x a(\sim k a)$ 'and also' on the other, have different syntactic constraints. $X a$ conjoins NPs, VPs or clauses (cf. 58), and it may conjoin all types of predicates (active predicates (cf. 57), stative predicates (cf. 59), and noun predicates (cf. 60)), whereas me excludes stative verbs. With active verbs, $x a$ signals simultaneous actions and refers to various aspects or subparts of the same event, whereas me tends to refer to sequential events. With stative predicates, $x a$ refers to the cumulative properties of an entity.

Kep-da mwa ye $\quad \boldsymbol{x} a$ keva roven hî wany. build-up ACT 3SG.FR also build finish this boat 'She works away and the boat is finished.'

$$
\begin{aligned}
& \text { Co xam cêe hulak xa co beega-ny. } \\
& \text { 2SG ASS very old also 2SG cousin-POSS-1SG } \\
& \text { 'You are very old and you are my cousin too.' }
\end{aligned}
$$

$$
\begin{aligned}
& \text { Je le wa-giik jahoot xe dâlâk } x \boldsymbol{x a} \text { hâk ava-t. } \\
& \text { be.(loc) there CLF-one river TOP deep also big side } \\
& \text { 'There is a river deep and wide.' (me would be ungrammatical here) }
\end{aligned}
$$

Pwaxi-m hoona $\boldsymbol{x a}$ fwamwa-m hoona $\boldsymbol{x a}$ gau-m...
child-POSS.2SG this.DEICT also country-POSs.2SG
... pwêêlô hoona.
flute this.DEICT also bamboo-POSS.2SG

'This is your son and this is also your country and this is also your flute.'

Table 3: Semantics of $m e$ and $x a$

\begin{tabular}{|l|c|c|}
\hline \multicolumn{1}{|c|}{ Simultaneous actions } & Sequential & Consecutive \\
\hline$x a$ & $*$ & $*$ \\
\hline$m e$ (no subj. index) & $m e$ (+subj. index) & $h m a . . m e$ \\
\hline
\end{tabular}

In contrast with me, predicates or clauses conjoined by $x a$ must have coreferential subjects; consequently, the personal index need not be expressed, and is generally not expressed. Coreference may be with a subset of the initial subject in the first clause, as in (61), where the parents (3DU hli) are a subset of the initial whole (parents and children):

(61) me hla u muиvi da mwa xa hli u maak mwa hlileny hulak. COORD3PL PFC stay up ACT also 3DU PFC die ACT these2.DEICT old 'And they (i.e. parents and children) live there to the south and the old ones die.'

When $x a$ conjoins active verbs, the actions are immediately sequential, cumulative and constitute one single event; whereas me refers to a sequence of different events.

(62) fhe mwa hooli waja-n xa pae-da ni penono paan take ACT this.ANAPH boat-POSS.3SG also throw-up in branch pandanus ' $(\mathrm{He})$ takes this boat and puts it up on the branch of a pandanus ... 


$$
\begin{array}{llll}
\ldots n a & \text { le me } i \quad u \text { oxuuri-ve } & \text { on. } \\
\text { LOC PR.ANAPH DEPEND 3SG ACC follow-DIR } & \text { sand } \\
\text { there and he walks along the beach.' } &
\end{array}
$$

In (63), the second occurrence of hobwaxe could be ellipted, resulting in NP conjunction:

(63) Na co muuvi me yo taa hobwaxe awôlôxa (hobwaxe)

CONTR 2SG stay DEPEND 2SG STAT watch home also watch

... hoona pwaxi-hî.

this.DEICT child-POSS.1DU.INCL

'But stay to watch our home and (watch) our child.' (Or:) 'But stay and watch our home and (watch) our child.'

$X a$ is indifferent to polarity and may conjoin negative clauses (64) or modify a negative verb (cf. 65):

$$
\begin{aligned}
& \mathrm{Na} \text { kia ho fwâ axi-e } \boldsymbol{x a} \text { kia ho fwâ mu } \\
& \text { CONTR there.is.no that yet see-3SG also there.is.no that yet stay } \\
& \text {...bwa dau eli. } \\
& \text { on island that.ANAPH }
\end{aligned}
$$

'But nobody has yet seen her and nobody has yet been on that island.'

$$
\begin{array}{llll}
B u \quad x u \quad k i a n & \boldsymbol{x a} \text { hleena habwali-ny. } \\
\text { EXPL PFC not.be.there also these.DEICT } & \text { clothes-POSS.1SG } \\
\text { 'Well, they have disappeared too.' }
\end{array}
$$

\subsection{Me, $n a$ and $x a$ in clause chaining}

These morphemes signal topic continuity or discontinuity as well as a samesubject vs. different-subject constraint.

\subsubsection{Me topic continuity vs. na topic discontinuity}

In sentence- or clause-initial position, $m e$ is a clause chaining device, marking topic and referential continuity (whether of argument or action), in contrast with $n a$ 'but, and then' which signals topic discontinuity, contrast or opposition. They also have different syntactic properties: $n a$ only conjoins clauses or sentences and is the default marker in sentence initial position, whereas $m e$ is less common in sentence initial position, unless topic continuity is stressed. Finally, and in contrast with me, $n a$ does not license subject pronoun ellipsis under coreference, which correlates with its topic discontinuity marking function.

Topic discontinuity concerns the actions and agents in $(66,67)$, and only the actions in (68):

(66) Na na pek me na tu tharaxila-na mwaidu, na hla CONTR 1SG avoid DEPEND 1SG go.down jump-1SG down.there CONTR 3PL

$$
\text { ...thu tho-nuat me hla khabwe: [...] }
$$

make call-mouth DEPEND 3PL say

'And/but then, I avoid them and jump away and then they call and say: [...].'

$$
\begin{aligned}
& \text { Hla oda hân hleena ak, na hla tu ni daak } \\
& \text { 3PL go.up hunt these.DEICT man CONTR 3PL go.down in garden } \\
& \text {... hleena thaamwa. } \\
& \text { these.DEICT woman } \\
& \text { 'The men go hunting and/whereas the women go to the gardens.' }
\end{aligned}
$$
Hla tu
me hla tu
kuut bwa on na hla axi bon ...
3PL go.down DEPEND 3PL go.down stand on sand CONTR 3PL see sea-gull
'They go down, they go down to the beach and then they see the sea-gull ... 


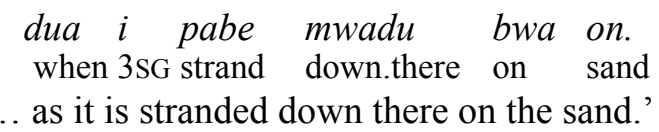

In (69), na signals discontinuous agents and actions, while me refers to sequential actions done by the same agents or by a subset of the same agents, and $x a$ indicates simultaneous actions with coreferential subjects.

Tu mwa oda shi horaamwaleny me hli u wo;

go.down ACT go.up side this.woman DEPEND 3DU ACC weave

'(She) then goes down, enters this woman's (house) and (then) they weave;

hli $u$ wo, na $i$ xau oome hiiji aaxiik $\boldsymbol{x a}$ fhe

3DU PFC weave CONTR 3SG ASS come ant CLF-one also carry

they weave, but then an ant suddenly comes in carrying ...

paara-khoo-n nu na mwelî me $i$ xauthegela.

crumb-food-POSS.3SG coconut LOC there DEPEND 3SG ASS run

a crumb of coconut pith from there and she suddenly runs.'

$\mathrm{Na}$ (or the topic marker $x$ e) also signals the topicalization of a temporal or conditional clause, thus marking contrast and another form of departure from the neutral order. Compare (70a) where the temporal clause is not topicalized, with $(70 \mathrm{~b})$, where it is topicalized.

(70)a. I $u$ yhaale idaama Pwâ-Hivic dua $u$ gi-hli mwada ara-xebö.

3SG PFC take.away eye Pwâ-Hivic when PFC be(LOC)-3DU up.there limitmangrove

'Pwâ-Hivic took out her eyes (from their sockets) when she was up there close to the mangrove.'

b. Dua u gi-hli mwada ara-xebö, na/xe $i$ u yhaale when PFC be(LOC)-3DU up.there limit-mangroveCONTR/TOP 3SG PFC take.away 'When she was up there close to the mangrove, then, Pwâ-Hivic took out

idaama Pwâ-Hivic na le.

eye Pwâ-Hivic LOC ANAPH.PR

her eyes there.'

\subsubsection{Xa and me: same-subject or different-subject constraint in clausal coordination}

$X a$ 'and also' imposes a same-subject constraint (cf. 71), whereas me is compatible with same or different subjects in the conjoined clause or VP. With me, a subject index is obligatory when the subjects are not coreferential (cf. 72); when the subjects are coreferential, the presence of a subject index signals sequential actions involving some temporal gap, as in (73) 'sleep and wake up', whereas the lack of subject index to the conjoined VP signals immediately sequential or simultaneous actions (74). It is then almost equivalent to $x a$.

(71) $I_{\mathbf{i}}$ oda Teâ Pwayili $i_{\mathbf{i}}$ shi Teâ Ovaac xa $(i)_{\mathbf{i}}$ khabwe ushi-n ... 3SG go.up Teâ Pwayili side Teâ Ovaac also (3SG) say BENEF-POSs.3SG

'Teâ Pwayili goes up to Teâ Ovaac and tells him ...'

$$
\begin{aligned}
& I_{\mathrm{i}} \quad \text { oda Teâ Pwayili } i_{\mathrm{i}} \text { shi Teâ Ovaac } \text { me }_{\mathbf{j}} \boldsymbol{i}_{\mathbf{j}} \text { khabwe ... } \\
& \text { 3SG go.up T. Pwayili side T. Ovaac DEPEND 3SG say } \\
& \begin{array}{lll}
\text {... ushi-n } & \text { a } & \text { Teâ } \text { Ovaac }_{\mathrm{j}} . . \\
& \text { BENEF-POss.3SG } & \text { AGT T. Ovaac }
\end{array}
\end{aligned}
$$

'Teâ Pwayili goes up to Teâ Ovaac and Teâ Ovaac tells him ...' 


$$
\begin{array}{llllllll}
\boldsymbol{I}_{\mathbf{i}} & \text { mago } & \text { alo } & \text { eli } & \text { me } & \boldsymbol{i}_{\mathbf{i}} \text { xau } & \text { not } & \text { dame } \\
\text { 3SG } & \text { sleep } & \text { child } & \text { this.ANAPH } & \text { DEPEND } & \text { 3SG ASS } & \text { wake.up } & \text { up.here } \\
& \ldots x \boldsymbol{x a} & (i)_{\mathbf{i}} & \text { gi. } & & & & \\
& \text { also } & \text { (3SG) } & \text { cry } & & & &
\end{array}
$$

'The child was sleeping and (then) he suddenly woke up and started crying.'

(74) $\mathrm{Na} i$ xam wâlem me $\boldsymbol{\varnothing}$ gi.

CONTR 3SG ASS walk DEPEND cry

'And she walks and cries.'

These facts are summarized in Table 4.

Table 4: Summary of predicate and clausal conjunction

\begin{tabular}{|l|l|c|}
\hline Conjunction & \multicolumn{1}{|c|}{ same subjects } & different subjects \\
\hline$m e$ & $\begin{array}{l}\text { without coreferential subject index: immediate } \\
\text { succession } \\
\text { with coreferential subject index: succession, aim }\end{array}$ & $\begin{array}{c}\text { with obligatory subject } \\
\text { index }\end{array}$ \\
\hline$x a$ & $\begin{array}{l}\text { with or without coreferential subject index: } \\
\text { simultaneousness or immediate succession }\end{array}$ & ungrammatical \\
\hline
\end{tabular}

\section{Typological comparisons with other Oceanic languages}

Two main issues will be discussed in this section. First, an analysis of appositive inclusory constructions in various Oceanic languages will support my claim that ellipsis is unnecessary to account for the inclusory properties of the coordinator in the northern New Caledonian languages. Secondly, some diachronic developments will be presented to account for the parametric changes evidenced by various Oceanic languages.

\subsection{Appositive inclusory constructions in some Oceanic languages}

Oceanic languages display a variety of inclusory constructions. Some of them, Manam (Lichtenberk 1983), Toqabaqita (Lichtenberk 2000) and Mwotlap (François 2000), dispense with any inclusory or conjunctive marker. The head is the inclusory pronoun and the appositive NP specifies an included subset:

(75) Mwotlap (François 2000:479; 391)
a. Inti-mamyo Wilson. son-1DU.EXCL Wilson 'It's the son of Wilson and me.' (= 'It's Wilson's and my son.')
b. Komyo ye ma-van me? Kamyo Wilson. 2DU who? PFC-go here 1DU.EXCL Wilson 'Who did you come with?' 'With Wilson.'

In Toqabaqita, there are two types of inclusory constructions, neither of them with any conjunctive marker. In the split type (cf. 76), the inclusory function is borne by a subject-index/tense marker (mere), whereas in the phrasal type [NP NP] (cf. 77), it is borne by a free pronoun (kamareqa) and a subject-index/tense marker (meki). In both cases, the speaker 'I' is included in the inclusory pronoun 'we $\mathrm{dual}$ '. In such constructions, constituent ellipsis has no explanatory value.

Toqabaqita (Lichtenberk 2000:3; 10)

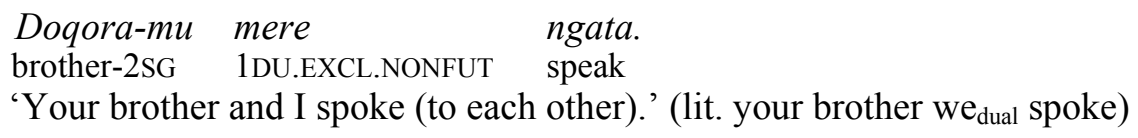


[Kamareqa doqora-ku] meki lae ma-i.

1DU.EXCL brother-1SG 1DU.EXCL.FUT go DIR-at

'I and my bother will come tomorrow.' (lit. we $\mathrm{e}_{\text {dual }}$ my brother we $\mathrm{e}_{\text {dual }}$ spoke)

In contrast, New Caledonian languages usually display a conjunctive marker, which suggests some structural evolution, but Ajië and Tîrî have traces of appositive inclusory constructions (see $\S 4.2$. and $\S 4.3 .2$.).

\subsection{Inclusory, coordinating and comitative strategies: a comparative overview in some Oceanic languages}

Inclusory constructions do not exclude other types of conjoining constructions, they often coexist with other coordination and comitative strategies. But inclusory constructions are mostly (if not exclusively) restricted to human referents, as in Mwotlap and Nêlêmwa. In Toqabaqita, the inclusory construction is different from but coexists with NP coordination with $m a$ (cf. 78).

(78) Toqabaqita (Lichtenberk 2000:8-9)

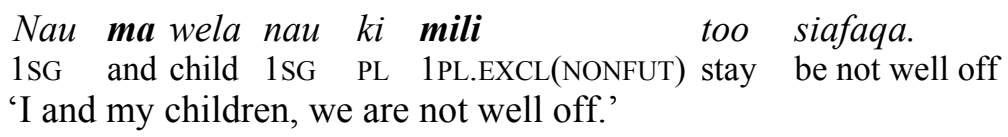

The comitative preposition bia 'with' (or its allomorph bii) does not trigger number concord, but it may combine with the inclusory construction to add a participant, as in (79).

(79) Kamaroqa tha Bita moki lae bii kamiliqa?

2DU PERS.MKR Bita 2DU go with 1PL.EXCL

'Will you and Bita come with us?'

In Manam (Lichtenberk 1983), the inclusory construction with number agreement (80) coexists with a comitative construction (81) marked by the postposition záiza without number agreement. Both the inclusory and the comitative constructions may be combined triggering plural number agreement again (82).

Manam (Lichtenberk 1983:430; 376; 432)

Nau to?a-gu Pé-ru Pi-réba-ru.

3SG.FR older brother-1SG 1DU.EXCL.FR 1DU.EXCL-sail-DU

'I and my older brother sailed.' (Or:) 'I sailed with my older brother.' (1983:430)

(81) Anúa ne-Ø i-láio nátu-Ø záiza.

village POSS-3SG 3SG-go child-3SG COMIT

'She went to her village with her child.' (1983:376)

\footnotetext{
On?au tári-Ø záiza di-sábar-i.

Onkau younger brother-3SG COMIT 3PL-hew-3SG

'Onkau hewed it with his younger brothers.' (1983:432)
}

In Ajië, a southern New Caledonian language, there are several available strategies: coordination with $m \tilde{a}$ (which conjoins NPs and VPs), an appositive inclusory construction (cf. 83-84), sometimes combined with the adverb vea 'together' (cf. 85) and a comitative preposition (cf. 88a below) or serial construction (cf. 88b): 
Ajië (Leenhardt 1932:196; 190; 199)

(83) Cere bori rhau toma rrua mã vi cere Orokau ${ }^{11 .}$

$3 \mathrm{PL}$ SEQ all stand up and go 3PL chief

'Then they all stood up and went with the chief.' (lit. ... and go they chief)

(84) Curu bori we vi-tavo curu kana $\chi i-\partial$.

3DU SEQ COMP REC-speak 3DU maternal.uncle POSS-3SG

'Then he talked with his maternal uncle.' (lit. they dual talked they $_{\text {dual }}$ maternal uncle)

Curu kuru ve mã сиги vea bwe-re.

3DU sleep for long 3DU together woman-that

'He slept with that woman for a long time.' (lit. they dual $_{\text {together that woman) }}$

Constructions such as those illustrated in (83)-(85) are still in use nowadays, as confirmed by a native speaker (A. Boehe, pers. com.) who stated that the use of $v \varepsilon a$ 'together' as in (85) is optional and emphatic. However in modern speech, an additional non-inclusory subject pronoun may appear (such as $n a$ in (86) and gö in (87a)), indicating some reanalysis which might in turn trigger the grammaticalization of the dual pronoun into a comitative marker. (For such a development, see the case of Tîrî in $\S 4.3 .2$ below).

Ajië (A. Boehe, pers. com.)

$\mathrm{Na}$ wakè curu yèvù.

3SG work 3DU chief

'He works with the chief.'

(87)a. Gö tëvë gövu pãdi-nyã.

1SG speak 1DU.EXCL brother-my

'I speak with my brother.'

When the subject index shows the same number as the inclusory pronoun, there must be a pause between the two segments, as in (87b):

b. Gövu təva, gövu pãdi-nyã.

1DU.EXCL speak 1DU.EXCL brother-my

'We dual $_{\text {speak, me and my brother.' (lit. we speak, we }}$ dual $m y$ brother)

There are two other comitative marking strategies without number concord, one with the preposition verri (cf. 88a) which is grammaticalized from the verb verri 'go, follow', the other with the comitative verb zara 'be together' (through serialization) (cf. $88 \mathrm{~b}$ ). Vèri is also used as a non-co-agentive 'with' marker: gö vi vèri rha karé 'I'm going with the basket'.

(88) Ajië

a. Na vi vèri-e.

3SG go with-3SG

'I speak with the chief.' (Aramiou et al. 2001:366)

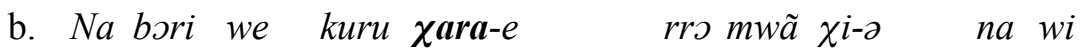

3SG SEQ COMP sleep be.together-3SG in house POSS-3SG SM man

'Then the man slept with her in his house.' (Leenhardt 1932:167)

As for the coordinator $m \tilde{a}$ (or $m \hat{e}$ in Tîrî), it never has the inclusory function that appears in the northern languages of New Caledonia; it is just an additive coordinator as in (89a-b); compare (89a) with the inclusory construction in (89c):

(89) Ajië (A. Boehe, pers. com.)
a. Gènyâ mã Paul.
1SG.FR COORD Paul
b. Gövu mã Paul.
1DU.EXCL.FR COORD Paul
c. Gövu
Paul
'Paul and I.'
'Paul and the two of us.'
1DU.EXCL.FR Paul
'Paul and I.'

11 The order is VOS when arguments are nominal, sVo with personal indexes, as in Nêlêmwa. 


\subsection{Inclusory constructions: paths of grammaticalization and replacement}

Coexistent and combined constructions (as in §4.2) show how former appositive inclusory constructions may lose some of their distinctive appositive features and start using additional coordinators which take on new inclusory functions, as evidenced by some northern New Caledonian languages. But there are other paths of reanalysis and grammaticalization, in particular the grammaticalization of an inclusory pronoun into a coordination marker (Mwotlap) or into a comitative preposition (Tîrî).

\subsubsection{Mwotlap (Vanuatu): reanalysis and grammaticalization of an inclusory pronoun into a coordination marker}

In Mwotlap (François 2000:389-90), the third person dual inclusory pronoun $k \overline{o y} \bar{o}$ (and only $k \overline{o y} \bar{o}$ ) is grammaticalized as a coordinator conjoining human NPs. Compare the inclusory construction (90) and the grammaticalized $k \bar{o} y \bar{o}(91)$ :

Mwotlap (François 2000:388; 262)

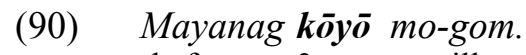

chef 3DU PFC-ill

'The chief (and her) are ill.' (lit. the chief they ${ }_{\text {dual }}$ are ill) (2000:388)

(91) imam k̄ōy tita mino

father 3DU mother my

'my father and mother' (2000:262)

The inclusory construction coexists with a comitative phrase tiwag $m i$ 'together with', which may be used both as a preposition expressing accompaniment or instrument without number concord $(92,93)$ or as a NP coordinator with number concord (94).

Mwotlap (François 2000:263; 262)

(92) ino, tiwag mi nēk

1SG.FR together with 2SG

'me and/with you' (2000:263)

(93) Nēk tog vanvan tiwag mi ige hōw en!

2SG PROH go together with PL down DEICT

'Do not go with the people down there (to the north)!' (2000:262)

(94) na-mañgo tiwag mi nō-wōh, kōyō vēlēs neneh vēlès.

ART-mango together with ART-coconut 3DU only sweet only

'The mango and the coconut are as sweet.' (2000:262)

\subsubsection{Tîrî (New Caledonia): grammaticalization of an inclusory pronoun into a comitative preposition}

In Tîrî (Osumi 1995), there are traces of a former appositive inclusory construction (with a first person dual or plural pronoun) without any conjunctive marker, but the inclusory pronoun has been grammaticalized into a comitative preposition, as evidenced by number agreement with the subject only, excluding the co-agent (cf. 95-96). The prepositional phrase can occur in different positions in the clause:

Tîrî (Osumi 1995: 40-41; 211)

(95)a. U fi kоти nrî pwere Numea.

1SG go 1DU.EXCL 3SG.FR to Noumea

'I go with him to Noumea.' (1995:40-41) 
b. Коти nrî u fi pwere Numea. 1DU.EXCL 3SG.FR 1SG go to Noumea 'With him, I go to Noumea.' (1995:40-41)

c. U fi pwere Numea komu nrî.

'I go to Noumea with him.'

(96) Nrorrù busi Sonya nrâ merro. $3 \mathrm{DU}$ cat Sonia 3SG sleep 'With the cat, Sonia sleeps.' (1995:211)

Such grammaticalization is probably correlated with a word order change in Tîrî, for though it still displays $\mathrm{V}(\mathrm{O}) \mathrm{S}$ order, $\mathrm{SVO}$ is becoming predominant. Thus, what was formerly a construction with two appositive pronouns (the inclusory free pronoun and a subject pronoun) such as fi komu nrî pwere Numea (lit. go we dual he to Noumea) was reanalyzed as follows: the inclusory pronoun grammaticalized as a preposition heading the following pronoun, while an additional subject pronoun appeared in pre-verbal position, as in (95)-(96). Reanalysis was facilitated by the fact that free pronouns and object pronouns are almost identical in Tîrî.

There is no trace of any asymmetric inclusory construction in Tîrî and NPs are conjoined by the coordinator $m \hat{e}$ (cf. 97). Various prepositions (Osumi 1995:82-87) mark co-agentive and non-co-agentive 'with' comitative roles, none of them triggering number concord.

(97) Tîrî (Osumi 1995:258)

Toni mê Nanu rru hôsi pwêvò.
Tony and Nanu 3DU buy egg
'Tony and Nanu bought eggs.'

\subsubsection{Conflation and replacement}

Merging is another factor of diachronic change and, in this respect, New Caledonian languages vary as to where they draw the line. The first tendency inversely correlates the existence of an appositive inclusory construction and the inclusory function of the coordinator 'and'. Thus, southern languages such as Ajië and Tîrî have an appositive inclusory construction (even though it is grammaticalized in Tîrî) and no inclusory function of the coordinator 'and'; while northern languages such as Nêlêmwa, Bwatoo and Cèmûhî evidence the inclusory function of the coordinator 'and', but no appositive inclusory construction. The second main tendency, represented by languages such as Drehu, Iaai (Loyalty Islands), Nemi (North) ${ }^{12}$ and Xârâcùu (South), is for the coordinator to conflate the inclusory, comitative and coordinating functions.

These tendencies also appear in other Oceanic languages: Toqabaqita, Manam and Mwotlap have distinct constructions, while Samoan ${ }^{13}$ and Tolai conflate all the functions under one and the same marker. In Tolai, $m a$ is both a conjunctive and an adjunctive morpheme which differs only in respect to number agreement: it conjoins NPs with number agreement (cf. 99), as well as VPs or clauses (Mosel 1984:94) and it marks instrumental and comitative adjuncts without number agreement (cf. 100). Compare Nêlêmwa: yamon ma ri? 'you and who else ?' (lit. you $_{\text {dual }}$ including whom?) and Tolai:

\footnotetext{
$12 m e$ in Iaai and $m a$ in Nemi mark the comitative function as well as NP, VP or clausal coordination.

13 Polynesian, Mosel and Hovdhaugen (1992:148).
} 
Tolai (Mosel 1984:41; 176; 176)

(98) Amur ma ia?

2DU COORD who?

'Who is with you?' (lit. you dual $_{\text {including whom?) }}$

(99) Telengai dir rovoi ma ra pap.

Telengai 3DU hunt with ART dog

'Telengai and the dog hunted.'

(100) Nam ra tutana $i$ ga rovoi ma ra pap.

DEM ART man 3SG TA hunt with ART dog

'That man hunted with the dog.'

In the various New Caledonian languages that have conflated such functions onto one morpheme, a syntactic device (number concord) or a lexical device (an adverb such as 'together') may disambiguate the comitative role from the coordinator. The comitative role does not trigger concord. In Xârâcùù ${ }^{14}$, mää is both a tight NP coordination marker and a comitative preposition (without number concord); it coexists with co-agentive or non-co-agentive comitative prepositions, wérè (+animate), kèrè (+/-animate) which do not trigger number concord. In Nyelâyu (spoken east of the Nêlêmwa area), the prevalent morpheme $m a$ (sometimes in variation with $m e$ ) conflates all the functions performed by $m a$ and $m e$ in Nêlêmwa. In contrast with Nêlêmwa $m a$, which only conjoins NPs with human reference, $m a$ in Nyelâyu may also conjoin inanimate NPs:

(101) Nyêlâyu (Ozanne-Rivierre 1998:119)

Ja na vuugeen ma dilic.

1PL.INCL put together with earth

'We mix it with earth.'

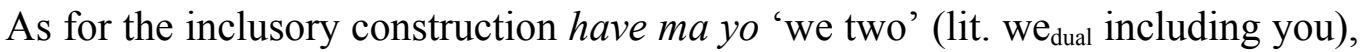
still used by older people, it is now being replaced among the younger Nyelâyu speakers by a non-inclusory construction with $m a$ or $m e$ (which is still considered less correct): yo ma ri? 'you and/with whom?' or yo me no 'you and me'.

\subsubsection{Some diachronic perspectives for me and ma in Nêlêmwa}

New Caledonian languages evidence various evolutionary paths. In Nêlêmwa, $m a$ and $m e$ might reflect three different Proto Oceanic coordinators: two conjunctions * $m a$ and *me 'and, with' and a comitative prepositional verb *ma-i (Moyse-Faurie and Lynch, this vol.). Ma (the reflex of Proto Oceanic *ma) has inclusory and comitative features; while me might result from the conflation of two proto-forms, the Proto Oceanic coordinator $* m e$ and the comitative prepositional verb *ma-i. This would explain optional number agreement in NP coordination with $m e$ : the Proto Oceanic coordinator *me would be cognate with the tight coordinator me with number concord, while *ma-i would be reflected by the loose coordinator or comitative me without number concord, as in ex. (4). This might also explain its marginal use as a non-co-agentive (associative) 'with' marker in place of the expected $v e, v i$ in ex. (5). Though synchronically, concord or lack of concord with $m e$ seems to vary with discourse and pragmatic considerations, it might well result from the fusion of two different morphemes with different number concord properties.

Togetherness and inclusion are the main distinctive semantic features for Nêlêmwa $m a$ and $m e$; in contrast with $m a$, the non-inclusory coordinator $m e$

\footnotetext{
${ }^{14}$ Moyse-Faurie (1995:140); Moyse-Faurie and Lynch (this volume, ex. 76).
} 
optionally expresses togetherness. Similarly, in English, 'with' expresses togetherness, while 'and' only has it as an optional interpretation: compare the girl leaves with the boy (together, +/-co-agentive) and the girl and the boy leave. But such analogy stops at the semantic level, as $m a$ is not a preposition heading a comitative adjunct, but is a hybrid inclusory-comitative conjoining marker.

\section{Conclusion}

Areal typology, comparative data and diachronic reconstructions lead us to hypothesize that the comitative coordinator $m a$ developed an inclusory function in the northern languages of New Caledonia, possibly due to some overlapping between inclusory and coordinating constructions and, later, due to the loss of appositive inclusory constructions. The two southern New Caledonian languages considered here (Ajië and Tîrî) seem to support this: they have appositive inclusory constructions (either synchronically or as grammaticalized traces) and the coordinator $m \tilde{a}$ or $m e \hat{~ d o e s ~ n o t ~ h a v e ~ a n y ~ i n c l u s o r y ~ f u n c t i o n . ~ S u c h ~ a r e a l ~ d a t a ~ s u g g e s t ~}$ this evolution rather than the reverse (i.e. an inclusory-comitative morpheme reanalyzed as a medial NP coordinator of the type NP $m a \mathrm{NP}$ ).

At the present stage, $m a$ in Nêlêmwa is a hybrid inclusory-comitative coordinator requiring obligatory number concord with the included arguments; but some divergent evolution and specialization might be predicted: either as a symmetric medial NP coordinator, as in (i) below, or as a comitative preposition together with the loss of number concord on the subject pronoun as in (iii), with an intermediate stage represented by the asymmetric inclusory construction in (ii):

(i) $s_{\text {incl. }} \mathrm{V} \mathrm{NP}_{\text {arg }} m a \mathrm{NP}_{\text {arg }}>$ coordinating function

(ii) $\mathrm{s}_{\text {incl }} \mathrm{V} \varnothing \quad m a \mathrm{NP}_{\text {arg }}>$ hybrid inclusory-comitative-coordinating function

(iii) $\mathrm{s} \quad \mathrm{V} \varnothing \quad m a \mathrm{NP}_{\text {arg }}>$ comitative preposition

Boumaa Fijian (Dixon 1988:157-61) displays a similar evolution: among younger speakers, ' $e i$ 'and, with' is being grammaticalized as a comitative preposition, together with the loss of number agreement (as in (iii)), while the older speakers only make use of the coordinating (i) or inclusory asymmetric constructions (ii), represented by examples (42a-b).

In Nêlêmwa, only one occurrence of $m a$ without number agreement (102) was found in the whole corpus, its status is thus uncertain and needs to be confirmed:

$\begin{array}{lllll}\mathrm{Na} \boldsymbol{i} \text { xam } & \text { wâlem axaleny aayo ma hlaabai yabwec avat. } \\ \mathrm{CONTR} 3 \mathrm{SG} \text { ASS } & \text { walk this.man chief COORD those.ANAPH follower few }\end{array}$ 'But the chief kept walking with some of his followers.' (me would be the expected form)

As for the general dependency marker me, which might result from the convergence and fusion of two Proto Oceanic forms (*me and *ma-i), one of its uses, without number concord, might reflect the Proto Oceanic comitative prepositional verb *ma-i. But since it is increasingly confused with the coordinator $m e$, the coordinator $m a$ might then be pushed towards specializing as a comitative preposition, as in (102), to maintain distinctive morphemes. If such an evolution was to be confirmed, it would be an interesting case of fusion and inversion, from AND to WITH function in the case of $m a$ and from WITH to AND in the case of $m e$ (the reflex of *ma-i). The present stage might well be transitional.

The other interesting typological feature of New Caledonian languages is the distinction between the co-agentive and non-co-agentive 'with', which is expressed 
by number concord and/or by morphemes which may originate either from a coordinator or a noun in the case of the co-agentive 'with' and from grammaticalized deverbal prepositions in the case of the non-co-agentive 'with'.

Linguistic variation and divergence thus results from changes in a language's parametric settings and syntactic constraints, in two possible directions, the maintenance of distinctive features or the conflation of morphosyntactic devices and functions.

\begin{tabular}{|ll|ll|}
\hline \multicolumn{5}{|c|}{ Abbreviations } \\
\hline ACT & actualising marker & FR & free (pronoun) \\
AGT & agent marker & FUT & future \\
ANAPH & anaphoric & INCL & inclusive \\
ART & article & IRR & irrealis marker \\
ASP & aspect & lit. & literal translation \\
ASS & assertive & LOC & localiser \\
ASSOC & associative & LOC.PRED & locative predicate \\
BENEF & beneficiary & NEG & negation \\
BF & buffer & NEG.PRED & negative predicate \\
CAUS & causative & PL & plural \\
CLF & classifier & POSS & possessive marker \\
COLL.OBJ & collective object & PERS.MKR & personal marker \\
COMIT & comitative & PFC & perfect \\
CONN & connector (preposition) & PROG & progressive \\
CONTR & contrastive marker & PROH & prohibitive \\
DEICT & deictic & PR & pronoun \\
DEM & demonstrative & REC & reciprocal \\
DEPEND & dependency marker & SG & singular \\
DIR & directional & SM & subject marker \\
DU & dual & TA & tense-aspect marker \\
DUR & durative & TOP & topic marker \\
EXCL & exclusive & TR & transitive marker \\
EXPL & explicative marker & & \\
& & & \\
\hline
\end{tabular}

\section{Oceanic languages and language sources}

- Western Oceanic:

- North New Guinea

Manam (Manam and Boesa Islands, Papua New Guinea; Lichtenberk 1983).

- Meso Melanesian

- South New Ireland subgroups:Tolai (East New Britain, Papua New Guinea; Mosel 1984).

- Eastern Oceanic:

- Southeast Solomonic

Toqabaqita (Malaita Island, Solomon Islands; Lichtenberk 2000).

- Remote Oceanic

- North Vanuatu: Mwotlap (François 2000),

- New Caledonian: Far North of Mainland: Nêlêmwa (Bril 2000, 2002), Nyelâyu (OzanneRivierre 1998), Yuanga (Haudricourt, unpubl. manusc.); North of Mainland: Bwatoo (Ehrhart and Rivierre, forthcoming), Cèmuhî (Rivierre 1980), Nemi (Ozanne-Rivierre 1979); South of Mainland: Ajië (Aramiou et al. 2001, Leenhardt 1932, La Fontinelle 1976), Tîrî (Osumi 1995), Xârâcùù (Moyse-Faurie 1995); Loyalty Islands: Drehu (Moyse-Faurie 1983), Iaai (Ozanne-Rivierre 1976).

- Central Pacific

- Eastern Fijian: Boumaa Fijian (Dixon 1988).

- Nuclear Polynesian

- Proto Samoic subgroup: Samoan (Mosel and Hovdhaugen 1992). 
Figure 1: Diagram of Oceanic languages (adapted from Ross et al. 1998)

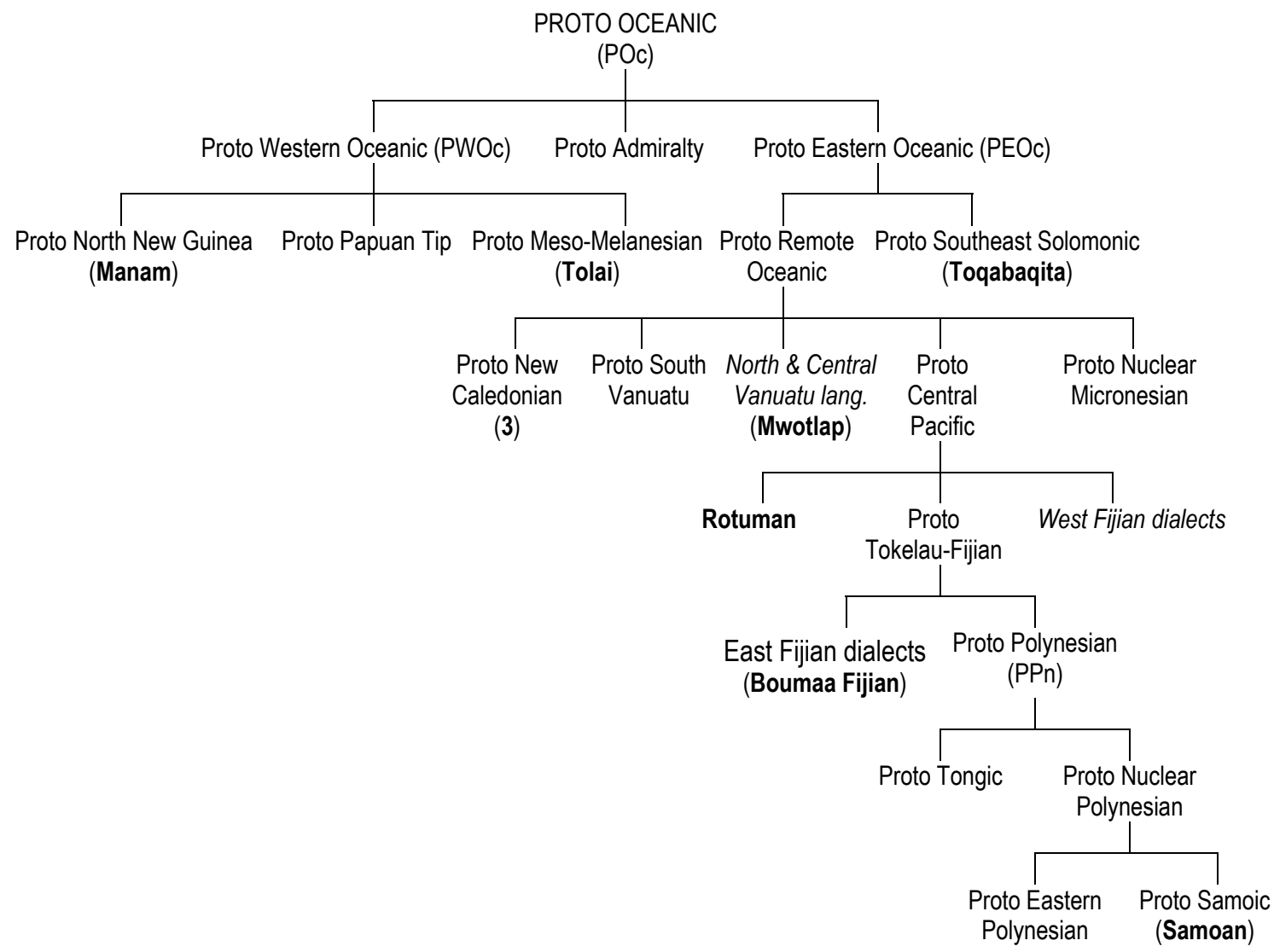

Notes:

1. The languages signalled in bold and between brackets are those mentioned in the article.

2. Italics are used to indicate a group of languages or a language which have no exclusively shared common ancestor.

3. Languages of New Caledonia : Far North of Mainland : Nêlêmwa, Nyelâyu, Yuanga ; North of Mainland : Bwatoo, Cèmuhî, Nemi ; South of Mainland : Ajië, Tîrî, Xârâcùù ; Loyalty Islands : Drehu, Iaai.

\section{References}

Aramiou, Sylvain et al.. 2001. Dictionnaire ajië-français, Nouméa, Collection Bwêwêyê, Fédération de l'Enseignement Libre Protestant.

Bril, Isabelle. 2000. Dictionnaire nêlêmwa-nixumwak-français-anglais. LCP 14. Paris: Peeters.

- 2002, Le nêlêmwa (Nouvelle-Calédonie): Analyse syntaxique et sémantique. LCP 16. Paris: Peeters.

Dixon, Robert M.W.. 1988. A grammar of Boumaa Fijian. Chicago: The University of Chicago Press.

Ehrhart, Sabine et Rivierre, Jean-Claude. To appear. Le Bwatoo et les dialectes de la région de Koné (Nouvelle-Calédonie). LCP 13. Paris: Peeters.

François, Alexandre. 2000. Contraintes de structures et liberté dans l'organisation du discours. Une description du mwotlap, langue océanienne du Vanuatu. PhD Dissertation, Université Paris IVSorbonne.

Johannessen, Janne Bondi. 1998. Coordination. New York: Oxford University Press.

Haspelmath, Martin. To appear. "Coordination". In: Shopen, Timothy (ed.), Language typology and linguistic description, $2^{\text {nd }}$ edition. Cambridge: Cambridge University Press.

Haudricourt, André-Georges. 1963. La langue des Nenemas et des Nigoumak. Te Reo Monograph. Auckland: Linguistic Society of New Zealand.

— n.d. Yuanga (unpublished manuscript, CNRS).

La Fontinelle (de), Jacqueline. 1976. La langue de Houaïlou. TO 17. Paris: SELAF.

Leenhardt, Maurice. 1932. Documents néo-calédoniens. Travaux et mémoires de l'Institut d'Ethnologie, IX. Paris: Institut d'Ethnologie.

Lichtenberk, Frantisek. 1983. A grammar of Manam. Oceanic Linguistics Special Publications 18. 
Honolulu: University of Hawaii Press.

— 2000. "Inclusory pronominals". Oceanic Linguistics, 39,1. 1-32.

Mosel, Ulrike. 1984. Tolai syntax and its historical development. Pacific Linguistics, Series B 92. Canberra: The Australian National University.

Mosel, Ulrike and Hovdhaugen, Even. 1992. Samoan reference grammar. Oslo: Scandinavian University Press.

Moyse-Faurie, Claire. 1983. Le drehu, langue de Lifou (Iles Loyauté). LCP 3. Paris: SELAF.

- 1995, Le xârâcùù, langue de Thio-Canala (Nouvelle-Calédonie). LCP 10. Paris: SELAF.

Moyse-Faurie, Claire and Lynch, John. To appear. "Coordination in Oceanic languages and Proto Oceanic". In: Haspelmath, Martin (ed.), Coordinating Constructions.

Osumi, Midori. 1995. Tinrin grammar (New Caledonia). Oceanic Linguistics Special publication 25. Honolulu: University of Hawaii Press.

Ozanne-Rivierre, Françoise. 1976. Le iaai. Langue mélanésienne d’Ouvéa (Nouvelle-Calédonie). Paris: SELAF 30.

- 1998. Le nyelâyu de Balade (Nouvelle-Calédonie). LCP 12. Paris: Peeters.

— 2004. "The Evolution of the Verb 'take' in New Caledonian Languages". In: Bril, Isabelle and Ozanne-Rivierre, Françoise (eds.). Complex predicates in Oceanic languages: Studies in the dynamics of binding and boundness. EALT, Mouton de Gruyter.

Rivierre, Jean-Claude. 1980. La langue de Touho. Phonologie et grammaire du cèmuhî. TO 30. Paris: SELAF.

Ross, Malcom; Pawley, Andrew and Osmond, Meredith (eds.). 1998. The lexicon of Proto Oceanic. Vol. 1. Material culture. Pacific Linguistics, Series B 92. Canberra: The Australian National University.

Stassen, Leon. 2000. “AND-languages and WITH-languages”. Linguistic Typology 4. Walter de Gruyter. 1-54,

- Forthcoming, "Some universal characteristics of noun-phrase conjunction". In: Plank, Frank (ed.), The Noun Phrase in the Languages of Europe. Berlin: Mouton de Gruyter. [EUROTYPE Publications 7]. 